\title{
Pengaruh Penerapan Sirip Dalam (Internal Fin) untuk Menghasilkan Uap Superheat pada Pembangkit Uap
}

\author{
Nuryanti, Adhitya Sumardi S., dan Suyono \\ Politeknik Manufaktur Negeri Bandung \\ Jl Kanayakan No. 21 - Dago, Bandung - 40135 \\ Phone/Fax : 022. $2500241 / 2502649$ \\ Email: nuryanti@polman-bandung.ac.id
}

\begin{abstract}
ABSTRAK
Permasalahan energi sekarang ini telah menjadi salah satu hal utama yang menjadi perhatian semua kalangan baik itu upaya dalam mencari sumber energi alternativ non fosil maupun upaya-upaya pengefisienan energi. Adapun salah satu upaya pengefisienan energi tersebut adalah dengan melakukan perancangan dan pembuatan system Pembangkit uap superheat yang menggunakan sirip dalam (internal fin). Uap superheat yang memiliki temperatur di atas $150{ }^{\circ} \mathrm{C}$ diharapkan dapat memberikan pemanasan yang lebih baik dibandingkan dengan pemanasan hanya dengan menggunakan air mendidih. Kegunaan sirip yang sebelumnya sebagai salah satu media pembuang kelebihan kalor maka dalam perancangan pembangkit uap superheat digunakan untuk memberikan kalor tambahan yaitu dengan memasangnya di dalam ketel pembangkit uap. Ketel dibuat dengan bahan stainless steel dengan ketebalan $2 \mathrm{~mm}$ dan berdiameter $20 \mathrm{~cm}$. Sedangkan sirip-sirip terbuat dari material yang sama namun dengan ketebalan $0.52 \mathrm{~mm}$ dengan dimensi $3 \mathrm{X} 10 \mathrm{~cm}^{2}$ sebanyak 10 buah. Air yang dipanaskan hingga mencapai keadaan uap jenuh akan mengalir melewati siripsirip dalam. Uap jenuh yang semula memiliki temperatur $100^{\circ} \mathrm{C}$ setelah melewati sirip dalam akan mendapatkan tambahan kalor sehingga memiliki temperature rata-rata $175{ }^{\circ} \mathrm{C}$ atau telah memasuki fasa superheat. Adapun debit aliran uap superheat rata-rata $5.4 \mathrm{ml} / \mathrm{menit}$. Adanya pemasangan sirip dalam telah meningkatkan penambahan kalor pada uap superheat hingga $60 \%$. Dalam percobaan pemanasan sampel makanan yang sama antara direbus secara konvensional dan menggunakan uap superheat maka setelah diamati selama 15 menit hasil dengan menggunakan uap superheat menunjukkan kondisi yang lebih matang.
\end{abstract}

Kata kunci: Sirip dalam, uap superheat, pembangkit uap superheat.

\begin{abstract}
The energy problem has been already a serious attention therefore exploring non fossil energy and attempting to increase the efficiency is really important. One to increase the energy efficiency is designing and building a Superheat Steam (SHS) generator with internal fins. Internal fins in SHS generator are used to provide additional heat in order to increase SHS temperatures until $150^{\circ} \mathrm{C}$ or more. SHS is expected to provide better heating than using boiling water. Internal fins have been attached around internal kettle as generator. The kettlehas been made of stainless steel with a thickness of $2 \mathrm{~m}$ mand adiameter of $20 \mathrm{~cm}$. Internalfins has been made of same as the kettle with a thickness of 0.52 mmand adimension of $3 X 10 \mathrm{~cm}^{2}$ as much as 10 pieces. In the kettle, water has been heated until reach $100^{\circ} \mathrm{C}$ saturated steam and flows up between internal fins. In the internal fins, saturated steam has addition heat by conduction, convection and radiation process so that saturated steam able to reach average temperature of $175{ }^{\circ} \mathrm{C}$ as superheated steam phase with flow rate reach $5.4 \mathrm{ml} /$ minutes. In this research, utilization of internal fins able to increase $60 \%$ of SHS temperature rather than without fins. Sample of food has been heated using SHS. In 15 minutes heating, sample of food is good enough cooked than sample of food using conventional boiling water
\end{abstract}

Keywords: Internal fin, superheated steam, superheated generator

\section{PENDAHULUAN}

Pemanfaatan uap jenuh terus berkembang baik dari skala rumah tangga, industri, transportasi misal pada kereta api sampai pembangkit tenaga listrik. Air yang dipanaskan pada temperatur $100^{\circ} \mathrm{C}$ dan pada tekanan $1 \mathrm{~atm}$ akan memasuki fasa cair jenuh hingga penambahan kalor meskipun sedikit akan menyebabkan air masuk ke fasa uap. [1] 
Penambahan kalor lebih lanjut pada tekanan tetap akan membawa uap ke fasa selanjutnya yaitu fasa superheat uap. Zat pada fase superheat selain memiliki temperatur yang tinggi juga bersifat kering. Dengan demikian superheat uap juga banyak digunakan di industri-industri untuk mengeringkan produk. Pengeringan produk-produk dengan superheat memiliki keunggulan antara lain energi uap panas akan dapat digunakan lagi. Sebagai contoh konsumsi energy sekitar 750 $\mathrm{KWh} /$ ton air yang diuapkan maka $70-90 \%$ dari energi tersebut dapat dimanfaatkan lagi untuk keperluan pemanasan lainnya atau bahkan dengan menghubungkannya ke turbin condensing akan menghasilkan listrik $200 \mathrm{kWh} /$ ton air yang diuapkan [2]. Selain itu pemanasan dengan uap mengurangi resiko yang ditimbulkan oleh api atau ledakan karena tidak menggunakan oksigen di dalamnya. Pengeringan dengan superheat uap juga menjaga kualitas produk misal pada industri makanan yaitu tetap menjaga kandungan gizi dan protein di dalamnya.

Pembangkitan uap superheat hingga saat ini seperti yang telah dikembangkan oleh Arun Mujundar [3] dan Amatsubo et all [4] adalah dengan membangkitkan terlebih dahulu uap jenuh pada suatu ketel. Uap jenuh tersebut kemudian ditarik dengan menggunakan blower ke suatu kamar (chamber). Di sepanjang pipa penyaluran diberikan pemanasan tambahan (external heater) sehingga temperatur uap jenuh akan bertambah menjadi $120^{\circ} \mathrm{C}$, dengan demikian Uap jenuh telah berganti fasa menjadi uap superheat. Kapasitas yang berhasil diberikan oleh Amatsubo et all [4], yaitu aliran uap superheat: $10 \mathrm{~g} / \mathrm{min}-30 \mathrm{~g} / \mathrm{min}$ dengan temperatur uap superheat berkisar antara $130^{\circ} \mathrm{C}-180^{\circ} \mathrm{C}$.

Dalam penelitian ini uap superheat diperoleh dari uap jenuh akan tetapi tidak menggunakan pemanas tambahan eksternal. Kalor tambahan diperoleh dari pelepasan kalor dari sirip sirip yang dipasang di dalam ketel. Dengan demikian diharapkan pemakaian energi yang lebih efisien dibandingkan dengan pemakaian pemanas eksternal.

\section{METODE PENELITIAN}

Metodologi dilakukan dengan membangun objek penelitian yaitu ketel uap superheat. Dimana ketel uap ini akan dibuat mudah dijinjing karena memiliki tujuan jangka panjang yaitu dapat digunakan oleh masyarakat luas. Oleh karena itu modifikasi sistem pemanasan atau pengeringan uap superheat konvensional menjadi sistem pemanasan/ pengeringan uap superheat portable akan dilakukan. Adapun skema pemanasan dengan uap superheat konvensional [3] seperti pada Gambar 1.

Untuk sistem pembangkit uap superheat yang portable maka ketel pemanas tambahan untuk menaikkan temperatur uap jenuh menjadi uap superheat yaitu berupa sirip-sirip yang dilas di dinding-dinding ketel dan ruang (chamber) untuk memanaskan/mengeringkan objek berada di dalam satu kesatuan yang kompak. Seperti yang terlihat pada Gambar 2.

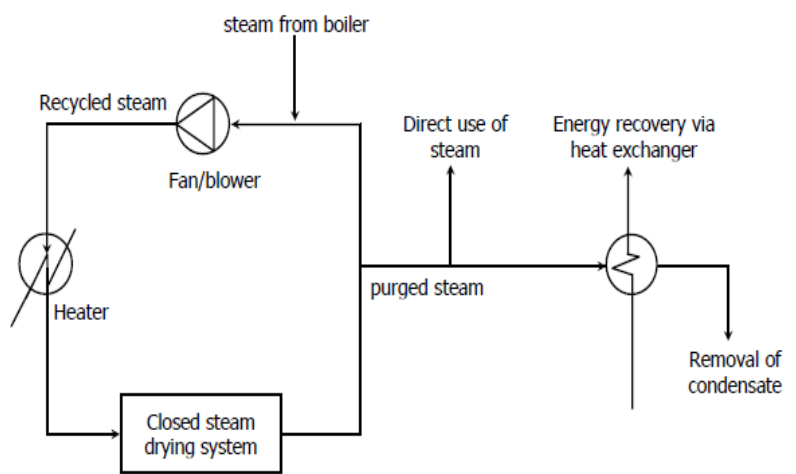

Gambar 1. Skema Pengeringan Menggunakan Uap Superheat

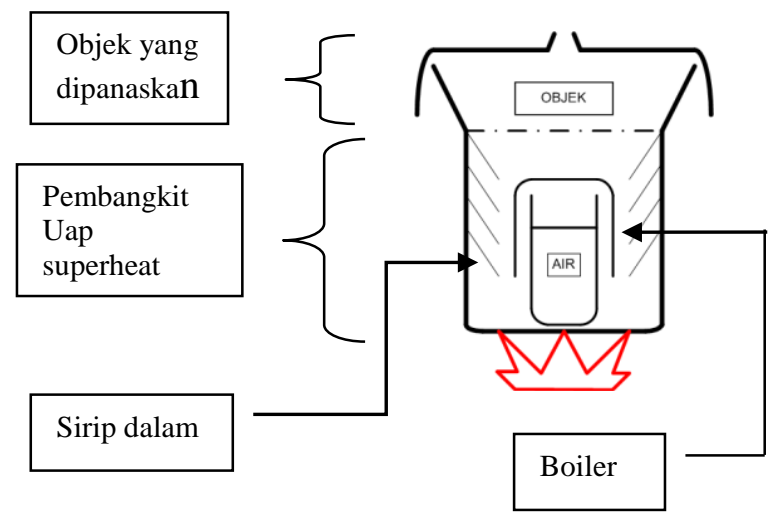

Gambar 2. Skema Pembangkitan Uap Superheat dan Sistem Pemanasan yang Kompak

Uap yang berasal dari air yang dipanaskan hingga $100{ }^{\circ} \mathrm{C}$ maka ketika uap air tersebut diarahkan untuk menyentuh sisi-sisi sirip yang memiliki temperature lebih tinggi, maka akan terjadi perpindahan kalor dari sirip ke uap air. Kalor tersebut meningkatkan temperatur uap air hingga memasuki fasa superheat. Dari sistem ini diperoleh karakteristik uap superheat sebagai berikut:

1. Laju aliran uap superheat: $5.4 \mathrm{mg} / \mathrm{menit}$

2. Temperatur uap superheat: $137^{\circ} \mathrm{C}-200^{\circ} \mathrm{C}$

3. Kapasitas ketel: 1 liter

\section{Perancangan Sirip}

Sirip sebagai salah satu bagian penting dari pembangkit uap superheat ini dirancang terlebih dahulu guna mendapatkan perpindahan kalor yang baik [5].

$\mathrm{T}_{\mathrm{b}}$

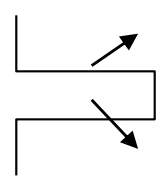

$\mathrm{T}_{\sim}$ 
Karena pada ujung sirip akan terjadi konveksi, maka diambil laju aliran kalor (qf) [6] adalah:

$q_{f}=M \tanh m L_{c}$

Dengan

$m=\sqrt{\frac{h P}{k A_{c}}} \operatorname{dan} M=\sqrt{h p k A_{c}}\left(T_{b}-T_{\infty}\right)$

Sedangkan efektifitas sirip adalah perbandingan laju kalor sirip dan laju kalor konveksi maksimum adalah:

$$
\begin{gathered}
\eta_{\mathrm{f}}=\frac{\mathrm{q}_{\mathrm{f}}}{\mathrm{q} \max }=\frac{\sqrt{h P k A_{c}}\left(T_{b}-T_{\infty}\right) \tanh \sqrt{\frac{h P}{k A_{c}}} L_{c}}{h A_{f}\left(T_{b}-T_{\infty}\right)} \\
=\frac{\sqrt{h P k A_{c}}\left(T_{b}-T_{\infty}\right) \tanh \sqrt{\frac{h P}{k A_{c}}} L_{c}}{h P L\left(T_{b}-T_{\infty}\right)} \\
\eta_{\mathrm{f}}=\frac{\tanh \sqrt{\frac{\mathrm{hP}}{\mathrm{kA}}} \mathrm{L}_{\mathrm{c}}}{\sqrt{\frac{\mathrm{hP}}{\mathrm{kAc}}} \mathrm{L}_{\mathrm{c}}}
\end{gathered}
$$

Atau dengan parameter

$\eta_{f}=\frac{\tanh m L_{c}}{m L_{c}}$

Dengan $m=\sqrt{\frac{h P}{k A_{c}}}$

Sirip pada penelitian dipilih yang berbentuk persegi. Dengan panjang $\mathrm{L}=30 \mathrm{~mm}$ dan ketebalan $\mathrm{t}$ $=0.52 \mathrm{~mm}$, maka $\mathrm{L}_{\mathrm{c}}=30+\mathrm{t} / 2=30.26 \mathrm{~mm}$, sedangkan $m$ merupakan parameter berupa:

$m=\left(\frac{h P}{k A_{c}}\right)^{1 / 2}$
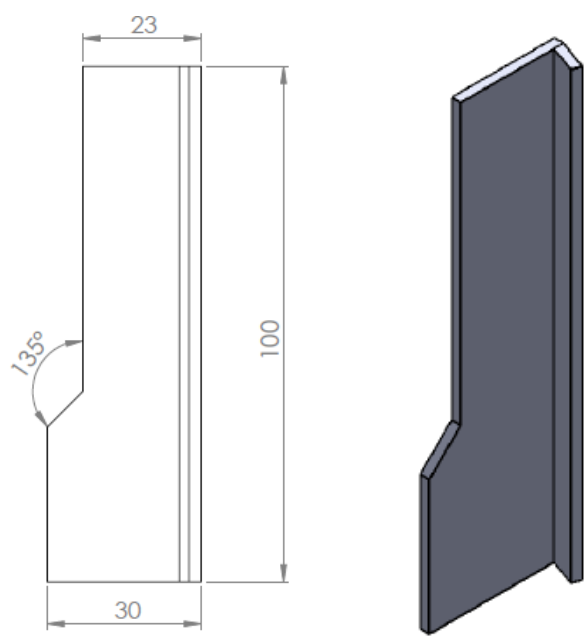

Gambar 3. Sirip Dalam pada Ketel Pembangkit Uap Superheat
Jika koefisien konveksi superheat (h) yang didekatkan dengan koefisien konveksi gas pada konveksi bebas yaitu 2-25 W/m²K [5]. Sedangkan karena uap superheat memiliki sifat-sifat yang tinggi terhadap udara maka h-nya juga tinggi, dengan demikian dipilih $\mathrm{h}=25 \mathrm{~W} / \mathrm{m}^{2} \mathrm{~K}$ dan $\mathrm{P}$ adalah perimeter dengan besar $\mathrm{P}=2(\mathrm{w}+\mathrm{t})$ dengan $\mathrm{t}$ jauh lebih kecil dari pada $\mathrm{w}$ maka $\mathrm{P}=2 \mathrm{w}=200 \mathrm{~mm}=0.2$ $\mathrm{m}$ dan $\mathrm{A}_{\mathrm{c}}=\mathrm{wt}=0.1 \times 0.52 \times 10^{-3}=52 \times 10^{-6} \mathrm{~m}^{2}$ maka $\mathrm{m}$, adalah,

$m=\left(\frac{25 \times 0.2}{15.1 \times 0.52 \times 10^{-4}}\right)^{1 / 2}=79.8$

Sehingga efisiensi sirip nya dari Persamaan (4)

$$
\begin{aligned}
& \eta_{f}=\frac{\tanh \left(79.8 \times 30.26 \times 10^{-3}\right)}{79.8 \times 30.26 \times 10^{-3}} \\
& \eta_{f}=\frac{\tanh 2.41}{2.41}=0.408
\end{aligned}
$$

Didapatkan bahwa efisiensi siripnya sebesar 40.8\%. Jumlah sirip yang dibuat berjumlah 10 buah.

\section{Perancangan dan Pembuatan Ketel Pembangkit Uap Superheat}

Setelah melakukan perancangan sirip dilanjutkan dengan perancangan dan pembuatan ketel Pembangkit Uap superheat dengan spesifikasi sebagai berikut:

1. Ketel Pembangkit Uap Superheat

Material : Stainless Steel

Ketebalan : $0.2 \mathrm{~mm}$

Diameter : $200 \mathrm{~mm}$

Ketinggian : $130 \mathrm{~mm}$

2. Ketel

Material : Stainless steel

Ketebalan : $1.22 \mathrm{~mm}$

Diameter : $120 \mathrm{~mm}$

\section{Persiapan Percobaan}

Percobaan dilakukan dengan mengukur temperatur di 4 titik dengan termokopel tipe $\mathrm{K}$ yang memiliki ketahanan kabel hingga $500{ }^{\circ} \mathrm{C}$ yaitu:

$\mathrm{T} 1$ : Temperatur air yang dipanaskan

T2 : Temperatur ruang antar sirip

T3 : Temperatur ruang antar sirip

T4 : Temperatur ketel bagian atas

Pengukuran dilakukan dengan interval waktu 3 menit. Volume air sebelum dan sesudah percobaan diukur untuk mendapatkan informasi banyaknya air yang berubah menjadi uap. Sumber kalor yang digunakan adalah gas stove yang memiliki katup untuk mengatur besarnya aliran gas sebagai bahan bakar. 
$\mathrm{T} 2$

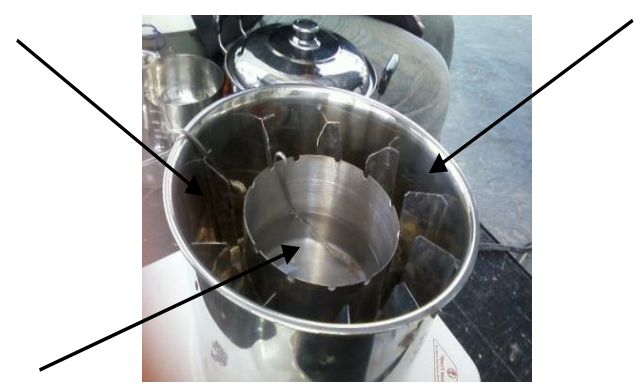

Gambar 4. Pembangkit Uap Superheat dan Titik Pengukuran

\section{HASIL DAN PEMBAHASAN}

Jika dilihat dari fenomena perubahan fasa air pada system pembangkit uap superheat ini, dapat diamati dari perubahan T1 atau temperatur air yang dipanaskan. Pada selang waktu antara 12 menit hingga 15 menit dari saat mulai dipanaskan air telah melalui fasa mendidih yaitu pada temperature $95-96{ }^{\circ} \mathrm{C}$ (Tekanan aktual di tempat percobaan kurang dari $1 \mathrm{~atm})$. Kemudian pemanasan yang makin berlanjut memberikan kalor terus menerus sehingga diperoleh Temperatur di sekitar sirip atau pun di bagian ketel atas berkisar antara 140-330 ${ }^{\circ}$ C.Pada temperatur tersebut maka uap air yang dihasilkan telah memasuki fasa superheat. Data distribusi temperatur berdasarkan waktu, dapat dilihat pada Gambar 6.

Data diambil pada titik-titik di dalam ketel pembangkit uap. Untuk $\mathrm{T}_{2}$ dan $\mathrm{T}_{3}$ adalah temperatur untuk ketel yang tidak menggunakan sirip sedangkan $\mathrm{T}_{2}$ dan $\mathrm{T}_{3}$ adalah yang menggunakan sirip. Di sini terlihat bahwa secara rata-rata temperatur uap di daerah ini telah tinggi yaitu di atas $100{ }^{\circ} \mathrm{C}$. Hal ini karena masih kuatnya pengaruh perpindahan kalor dari dinding ke uap jenuh secara konveksi Pengaruh panas dari dinding-dinding ketel, sisi boiler, dan pelat-pelat sirip memberikan kontribusi kalor sehingga pengukuran temperatur di daerah ini masih relatif tinggi dan perbedaan penggunaan sirip maupun tidak perbedaannya tidak terlampau jauh. Temperatur rata-rata sebelum memakai sirip adalah $199{ }^{\circ} \mathrm{C}\left(\mathrm{T}_{2}\right)$ dan 211 ${ }^{\circ} \mathrm{C}\left(\mathrm{T}_{3}\right)$ sedangkan yang telah memakai sirip $220^{\circ} \mathrm{C}$ $\left(\mathrm{T}_{2}\right)$ dan $250{ }^{\circ} \mathrm{C} \quad\left(\mathrm{T}_{3}\right)$. Namun terlihat bahwa penggunaan sirip mampu menaikkan temperatur di daerah itu hingga $14 \%$.

Ketika uap superheat mengalir ke ketel atas, temperatur kembali diukur. Terlihat yang menggunakan sirip dan tidak terdapat perbedaan temperatur yang cukup signifikan. Rata-rata temperatur superheat yang memakai sirip mencapai $174.7{ }^{\circ} \mathrm{C}$ $\left(\mathrm{T}_{4}{ }^{\prime}\right)$ dan rata-rata temperatur yang tidak menggunakan sirip yaitu $109.1{ }^{\circ} \mathrm{C}\left(\mathrm{T}_{4}\right)$. Terlihat ada kenaikan temperatur sebesar $60 \%$.

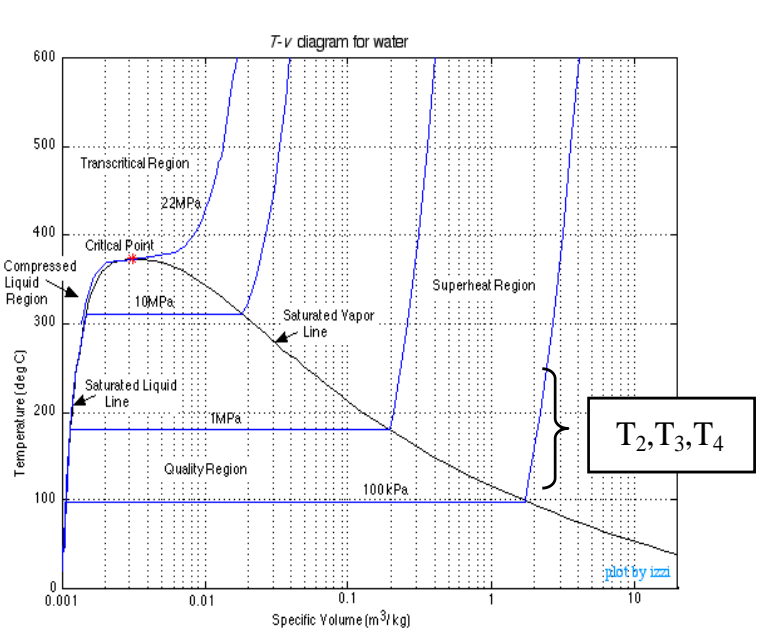

Gambar 5. Diagram Mollier Hasil Eksperimen

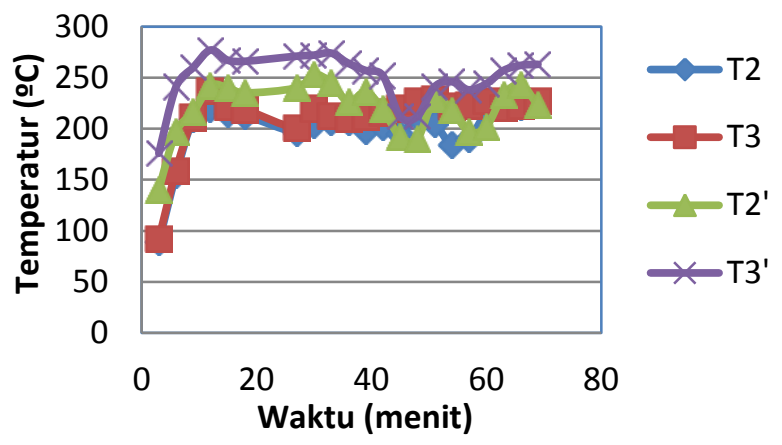

Gambar 6. Perbandingan Menggunakan Sirip dan Tidak Menggunakan Sirip Titik Ukur di Ruang antar Sirip

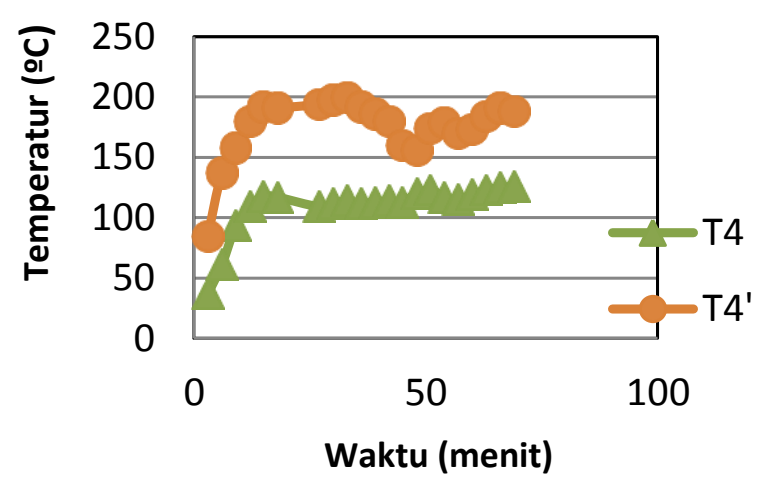

Gambar 7. Perbandingan Temperatur Uap Superheat Menggunakan Sirip dan Tidak Menggunakan Sirip di Ruang Pemanasan

\section{Laju Aliran Kalor Melalui Sirip}

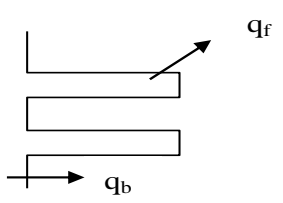

Jika $A_{b}$ adalah permukaan dinding, $A_{f}$ adalah luas permukaan sirip tunggal dan $A_{t}$ adalah luas 
total, $A_{t}=A_{b}+N A_{f}$, dan $\mathrm{N}$ adalah jumlah sirip. Untuk itu maka laju aliran kalor total pada sistem pembangkit uap superheat ini dimana jumlah sirip, $\mathrm{N}=10$, Luas sirip $=3 \times 100 \times 10^{-6} \mathrm{~m}^{2}$, Luas dinding yang berbentuk silinder adalah $2 \Pi \times 110 \times 130 \times 10^{-6} \mathrm{~m}^{2}$ dan temperatur dinding, $\mathrm{T}_{\mathrm{b}}=385^{\circ} \mathrm{C}$ dan temperatur uap superheat di sekitar sirip, $\mathrm{T}_{\infty}=250^{\circ} \mathrm{C}$ adalah [7] $q_{t}=q_{b}+N q_{f}$

$=h A_{b}\left(T_{b}-T_{\infty}\right)+N \eta_{f} h A_{f}\left(T_{b}-T_{\infty}\right)$

$=25 \times 2 \pi \times 110 \times 130 \times 10^{-6} \times(385-250)+$

$$
10 \times 0.408 \times 25 \times 30 \times 100 \times 10^{-6}(385-250)
$$

$=344.55 \mathrm{~W}$

\section{Distribusi Temperatur}

Pengujian pertama adalah melihat fenomena ketika uap superheat tidak dialirkan ke bagian atas dengan meniadakan lubang ketel atas. Dengan demikian uap superheat kembali tersirkulasi di dalam ketel pembangkit uap superheat. Adapun secara grafik perubahan temperatur T, T2, T3 dan T4 terlihat pada Gambar 8.

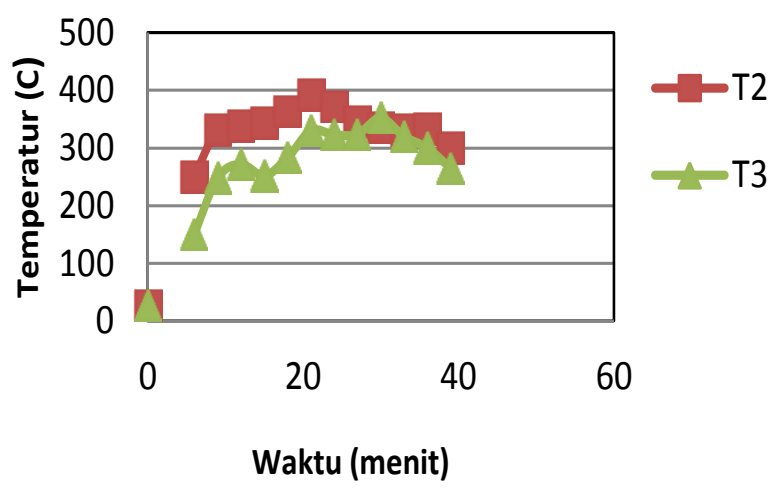

Gambar 8. Distribusi Temperatur Tanpa Aliran Uap Superheat

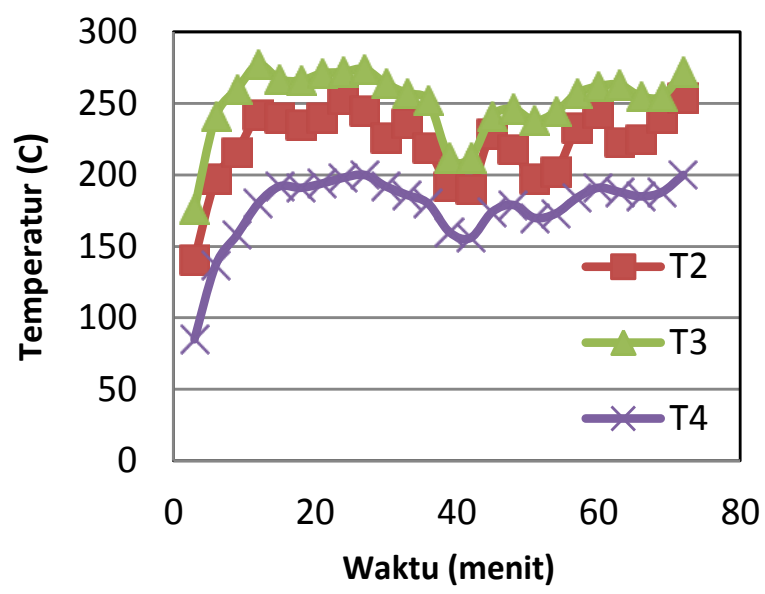

Gambar 9. Distribusi Temperatur dengan Aliran Uap Superheat
Dari Gambar 8 dan 9 terlihat bahwa uap superheat yang tidak dialirkan temperaturnya akan lebih tinggi di bagian ruang antar Sirip (T2) dibandingkan dengan yang dialirkan. Hal ini dikarenakan kalor dari superheat terus disirkulasikan pada ruang yang sama sehingga temperatur menjadi naik. Sedangkan pada superheat yang dialirkan ke bagian atas terlihat bahwa temperatur pada ketel atas (T4') lebih tinggi dibandingkan dengan yang tidak dialirkan dan hanya melakukan konduksi terhadap bagian bawah ketel. Jika dirata-ratakan maka perbedaan uap superheat yang dialirkan dan yang tidak di ruang antar sirip sebesar $89.9^{\circ} \mathrm{C}$ atau jika dipresentasekan bahwa penurunan temperatur uap superheat akibat pengaliran uap ke atas sekitar $30.2 \%$, sedangkan untuk temperatur di bagian ketel atas perbedaannya sekitar $43.1{ }^{\circ} \mathrm{C}$ atau terjadi peningkatan uap superheat pada ketel bagian atas sekitar $26.5 \%$.

\section{KESIMPULAN}

Uap superheat berhasil dibangkitkan yaitu dengan indikasi temperatur uap yang dihasilkan berkisar $140^{\circ}-330^{\circ} \mathrm{C}$. Penerapan sirip dalam pada generator superheat dapat meningkatkan temperatur uap hingga $60.2 \%$ dengan efisiensi design sirip $40.8 \%$ dan laju aliran kalor dari 10 buah sirip ke uap jenuh $344.55 \mathrm{~W}$.

\section{UCAPAN TERIMA KASIH}

Terima kasih ditujukan kepada Kementerian Pendidikan Nasional Indonesia atas Hibah Bersaing yang diberikan sebagai sumber pendanaan penelitian, sehingga penelitian dapat berlangsung dengan baik.

\section{DAFTAR PUSTAKA}

[1] Cengel Yunus, Bols Michael, Thermodynamic an Engineering Approach, (1994) Mc Graw Hill, Inc.

[2] http://www.barr-rosin.com/products/superheated-steam-drying.asp, diakses tgl 18-9-2012.

[3] Arun Mujumundar, Sakamon Devahastin, Drying Technology, 22, pp. 1845-1867, 2004.

[4] Tomone Amatsubo, Yoshio Hagura, Kanichi Suzuki, Heat Transfer Characteristic of Superheat Steam Combined with Far Infra red, Food Science Technology, Res, 11(4),pp. 363-368, 2005

[5] Incropera, F.P and DeWitt,D.P, Fundamental of Heat and Mass Transfer, $4^{\text {th }}$ Ed (1996), John Wiley \& Son, Canada.

[6] Fin Tutorial, Fluent Inc (Flow Lab), April 12, 2007.

[7] Fin design ppt, www.engr.iupui.edu/thermal, diakses tanggal 15-9-2012.

[8] http://www.ohio.edu/mechanical/thermo/Intro/Ch apt.1_6/Chapter2a.html6. 